\title{
RISK OF DEBT-BASED FINANCING IN INDONESIAN ISLAMIC BANKING
}

\author{
Kharisya Ayu Effendi
}

\begin{abstract}
Risk of Debt-Based Financing on Indonesian Islamic Banking. The purpose of this study is to know the risk of debt-based financing in Islamic banking in Indonesia by using an accounting based calculation, those are NPF analysis, Credit risk $Z$-score and Altman $Z$-score. This study is telling about the risk of debt-based finacing on Indonesian Islamic banking using an accounting based measurement, those are NPF analysis, Credit Risk Z-score analysis and Altman Z-score analysis. The data was obtained from 2011 to 2015 from the website of each bank. The result is a risk on debt-based financing on Indonesian Islamic is low. The measurement using 3 accounting based measurement tool gives a consistent result, that is Indonesian Islamic banking use a debt-based financing have a high financial stability and a low risk.
\end{abstract}

Keyword: financing risk management, debt-based financing, accounting-based

\begin{abstract}
Abstrak. Risiko Pembiayaan Berbasis Hutang pada Perbankan Syariab di Indonesia. Tujuan dari penelitian ini adalah untuk mengetahui resiko debt-based financing pada perbankan islam di Indonesia dengan menggunakan perhitungan accounting-based yaitu NPF analysis, Credit risk Z-score dan Altman $Z$-score. Penelitian ini menjelaskan resiko pada debt-based financing perbankan islam yang ada di Indonesia menggunakan accounting based measurement, yaitu NPF analysis, Credit Risk Z-score analysis dan Altman Z-score analysis. Data yang diperoleh sejak tahun 2011 hinggan tahun 2015 yang diperoleh dari website masing-masing bank. Hasilnya adalah resiko pada debt-based financing perbankan islam yang ada di Indonesia ini rendah. Pengukuran dengan menggunakan 3 alat ukur accounting based memberikan hasil yang konsisten yaitu perbankan islam di Indonesia menggunakan debt-based financing memiliki stabilitas keuangan yang tinggi dan resiko yang rendah.
\end{abstract}

Kata kunci: manajemen risiko pembiayaan, pembiayaan berbasis hutang, berbasis akuntansi 


\section{Introduction}

The global financial crisis in 2008 was the worst economic or financial crisis since the great depression in the 1930s, it was due to excessive lending and negligence committed by the bank in the long term. The financial crisis that occurred in the United States have had an impact on the global economic crisis reminds us about the importance of improving the credit risk management. Among many banks that have failed, Islamic banks have attracted the attention of all Muslim countries as well as non-Muslim countries, Islamic banking untill recently regarded as a development of financial institutions in the banking industry.

Research on comparison of Islamic banks and conventional banks have been widely performed. Among them about efficiency (Beck, et.al, 2013; Johnes, et.al, 2012; Kamaruddin, et.al, 2008); Profitability (Alkassim, 2005; Haron, 2004; Zaini, et.al, 2010) and Performance (Ariss, 2010; Hasan \& Dridi, 2010). Since the global crisis, many studies have been raised about the stability or credit risk in Islamic banking and conventional banking.

In the Islamic banking is not known about the credit system, but the financing system. This is because the Islamic banking forbids interest rate in the profit used in the credit system. While the financing system in Islamic banks use profit margin and profit and loss-sharing system (PLS) in acquiring profit. Financing system in Islamic banking is divided into two, namely Equity-based Financing and Debt-based Financing. Equity-based Financing are Mudharabah and Musyarakah, the gain is using a profit and loss-sharing system (PLS). Debt-based Financing are Murabahah and Ijarah, the gain is using profit margin, which are systems that determine the advantages of an item specified in the initial contract, so that the installments paid by the debitor remains the same.

In this study, just use Debt-based Financing (DBF) because the system is more risky than the Equity-based Financing system (EBF) (Shahari, et.al, 2015). And the most widely financing issued by Islamic banks in Indonesia is DBF financing compared to EBF. As can be seen in the Table 1.

Table 1 Financing Islamic Banking in Indonesia 2009 - 2015

(Billion rupiah)

\begin{tabular}{lrrrrrrr}
\hline Financing & $\mathbf{2 0 0 9}$ & $\mathbf{2 0 1 0}$ & $\mathbf{2 0 1 1}$ & $\mathbf{2 0 1 2}$ & $\mathbf{2 0 1 3}$ & $\mathbf{2 0 1 4}$ & $\mathbf{2 0 1 5 ^ { * }}$ \\
\hline DBF & 29.877 & 44.926 & 73.466 & 107.815 & 130.635 & 135.635 & 134.955 \\
EBF & 17.009 & 23.255 & 29.189 & 39.690 & 53.499 & 63.741 & 68.939 \\
\hline
\end{tabular}

Note: Source ojk, Islamic banking statistic

* data until June 2015 
There are three categories of creadit risk measurement: market based, external agencies and accounting based (Allen \& Powell, 2011; Altman \& Saunders, 1998). Market based category are Credit matric, Value at Risk (VaR) and Merton probability of default. Then, external agencies is a rating assessment of an agency, there are standard and poor, and moody provide rating specific for the company. The next category is accounting based, there are NPL analysis or in Islamic banking known as NPF (non-performing financing) Credit risk and the Z-score Altman Z-score. The purpose of this study is to know the risk of debt-based financing in Islamic banking in Indonesia by using an accounting based calculation, those are NPF analysis, Credit risk Z-score and Altman Z-score.

\section{Literature Review}

The main risk faced by bank is credit risk. This risk arisen from the possibility of default with the counterparty, for example, promised cash flows on the main effects owned by the bank cannot be paid in full. Credit quality problems can lead to bankruptcy of banks or will significantly drain on bank capital and net worth. This, in turn, can affect the growth prospects of the bank and its ability to compete with domestic and other international bank (Saunders, 2008).

Risk management for Islamic banking institutions regulated in the form of prudential standards were made for the availability of funds, by the Islamic Financial Services Board (IFSB). In the Islamic bank, credit risk depends on the type of financing structure. Such as, the risk of the debt-based financing is higher than in the structure of equity-based financing. However, even if the risk is larger, bank prefer choosing debt-based financing due to the collateral and guarantee returns that have remained determined in the initial agreement (Shahari et al., 2015). Musyarakah, mudarabah, istisna, salam, ijarah and murabahah are the main contracts used by Islamic banks to provide facilities to their customers. There are two classifications of this contract which can be used to distinguish between creating a mode of non-debt Islamic financing or equity-based (musharakah and mudarabah) and creating a mode of debt or debt-based (istisna, salam, ijarah and murabahah) (Kahf, 2005).

Murabahah contract is a financing contract which is most often used by Islamic banks. $80 \%$ to $90 \%$ financing in Islamic banking lies in this murabahah contract. This contract is used to finance consumer durables, real estate, industry in the purchase of raw materials, machinery and equipment. This contract determines the profit margin at the beginning of the agreement made by banks and consumers, so consumers only have to add up the prices of goods and profit margins, and then divided by time due to pay. This murabahah contract can be said to be similar to the general credit in the conventional banks, but the monthly payment is fixed, not changing like interest rate in the conventional banks. This principle is more advantageous for consumers 
because whatever happens in the economic conditions of a country, the payment will not increase. This principle is also more favorable to keep an economic stability of a country, a result of fluctuation in the interest rate causes instability and inflation.

While Ijarah is a transfer agreement of rights or benefits of a good or service by paying rent for a certain period of time without being followed by the transfer of rights ownership of the goods. Bank Indonesia defines the Ijarah as a leasing agreement of good within a specific time through lease payments. Ijarah as a transfer contract of rights for goods or services through lease payments without the ownership of the goods themselves. As-salam is buy goods which it's delivery performed later in the day while the payment carried out in advance in cash. As-salam in banking is usually applied to short-term financing for the production of agribusiness or agriculture or other industries. Istisna basically is a sales contract between the buyer and the manufacturer of goods with the payment in advance, either done by cash, mortgage, or deferred.

\section{Method}

The method used in this study is an accounting based method, which consists of NPF analysis, Credit risk Z-score and Altman Z-score. The data obtained in this study are the 7 Islamic banks in Indonesia: Bank of Muamalat, Bank of BCA Sharia, Bank of BNI Sharia, Bank of BRI Sharia, Bank of Sharia Mandiri, Bank of Panin Sharia and Bank of Sharia Bukopin. The data were used from 2011 to 2015.

NPF analysis using ratio analysis is total NPF divided by total net lending.

$N P F$ ratio $=$ Total NPF $/$ Total net financing

The higher the NPF ratio, then the ratio of bankruptcy or failure is also higher. This has been arranged by Bank Indonesia, the central bank in Indonesia by setting the NPF/NPL is good at either not exceed from 5\%. One advantage of using the NPF as a credit risk measurements, it's measurement is directly from the bank's solvency and it was difficult to be manipulated by management.

Credit risk Z-score is a measurement technique most commonly used to measure financial stability in the banking system (Beck et.al., 2013; Boyd \& Nicoló, 2003; Cihak \& Hesse, 2008). The calculation is

$$
\mathrm{Z} \text {-score }=(\mathrm{ROA}+\mathrm{E} / \mathrm{A}) / \mathrm{SD} \text {. Of ROA }
$$

Where ROA is the return on assets or net profit after tax divided by total assets, while $\mathrm{E}$ is the total equity and $\mathrm{A}$ is total assets, $\mathrm{SD}$. Of ROA is the standard deviation of $\mathrm{ROA}$ over three years. The reason to use credit risk $\mathrm{Z}$-score is as a measurement of bank soundness between academics and practitioners. One of them is this measurement is easier to use than a market-based measurement tool such as credit metrics or VaR, and accounting information required only a little, but this tool is superior compared to other accounting measures such as NPF analysis. Another reason is the accuracy of this tool, 
the measurement of credit risk Z-score is inversely proportional to failure, if the Z-score is small then the failure rate will be high and vice versa if the $Z$-score is big then the failure rate will be small. (Cihak \& Hesse, 2008) studying the power of $Z$ scores in predicting bank failures that have a risk of systematic failure. According to their findings, the banks that failed during the crisis had significantly lower $\mathrm{Z}$ scores than other banks do not default. This clearly shows that the $\mathrm{Z}$ score is one of the most powerful measurement tool to measure the stability of the bank.

Altman Z-score is a company failure measurement tool. Altman Z-score has 3 different technique namely manufacturing companies that have go public, manufacturing companies that have not go public and non-manufacturing companies. The data in this study is on banking, the technique used is the Altman Z-score of non-manufacturing companies. Which can be formulated with,

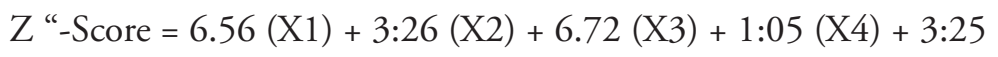

Where $\mathrm{X}_{1}$ is a working capital/total assets, $\mathrm{X}_{2}$ is a retain earnings/total assets, $\mathrm{X}_{3}$ EBIT/total assets and $\mathrm{X}_{4}$ is an equity(book value)/total liabilities(Altman \& Saunders, 1998). The interpretation is that if $\mathrm{Z}>2.99$, the company don't have a problem with the financial conditions. If $1.8<Z<2.99$, the company has a little problem in the financial condition (this is not too serious). If $Z<1.88$, the company experienced a serious problem (Saunders, 2008).

\section{Result and Discussion \\ Non-Performing Financing Analysis}

In Figure 1 is a non-performing loan of the data, which is debt-based financing, not the whole of the expenses on each bank. The data obtained based on the annual financial statements for each bank through their respective websites. Data non-performing financing is debt-based financing is substandard or not that smooth, doubtful and loss is then divided by total debt-based financing. The results showed that the ratio of NPF on each Islamic banking in Indonesia have a low risk of debt-based financing or can be said that Islamic banking in Indonesia have a good financial stability, because the ratio of NPF is still below $5 \%$ or still below the ratio NPF determined by Bank Indonesia (BI) as a central bank. Bank of BCA sharia has a NPF ratio from 2011 to 2015 below 0\%. Bank of BNI sharia has a NPF ratio below $2 \%$ for the last 5 years. While Bank of BRI sharia, Bank of sharia Bukopin, Bank of sharia Mandiri, and Bank of Muamalat have NPF ratio higher than 3 other banks that is average by $3 \%$ but still below $5 \%$ in last 5 years. Bank of Panin sharia has a relatively low NPF ratio in 2011 - 2014 of 1\% but in 2015 the NPF ratio jumped quite high by $3.5 \%$. The increase is due to the increase in financing that occurred in the previous year. This result is consistent with the results of the research 
(Kabir et.al, 2015), which revealed that NPF on Islamic banking showed a lower risk against credit risks. Other researchers who studied the credit risk analysis of NPF is (Ahmad, 2007; Berger \& Deyoung, 1997; Das \& Ghosh, 2009; Jiménez, et.al, 2007; Sukmana \& Suryaningtyas, 2016)

Figure 1. DBF Non Performing Financing Ratio

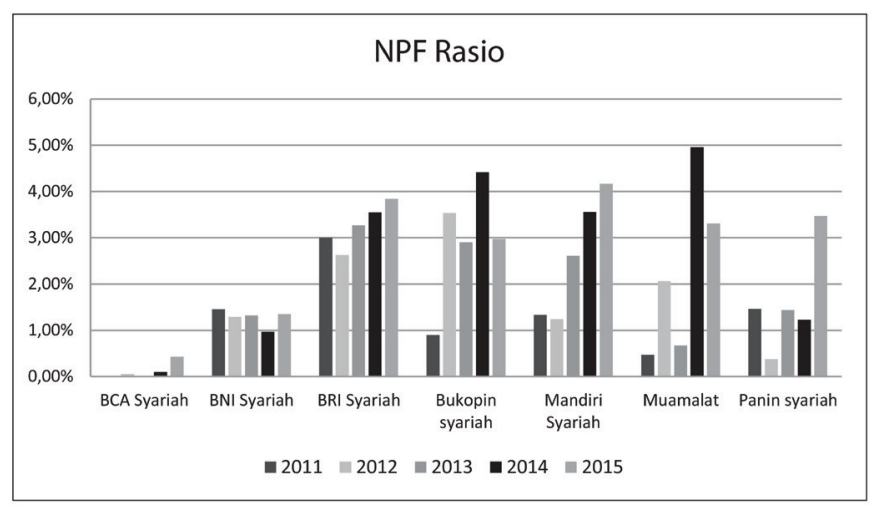

Source: website each Islamic banking and calculate

\section{Credit Risk Z-Score Analysis}

This Z-score credit risk analysis using the ROA data, total assets, total equity and a standard deviation of ROA that minimum can be accurately performed when the data is taken from more than three years. The result can be said to be stable or away from a possible default if the farther from zero towards the positive, and the greater the value, the better to maintain the stability of Islamic banking.

Figure 2. Credit Risk Analysis

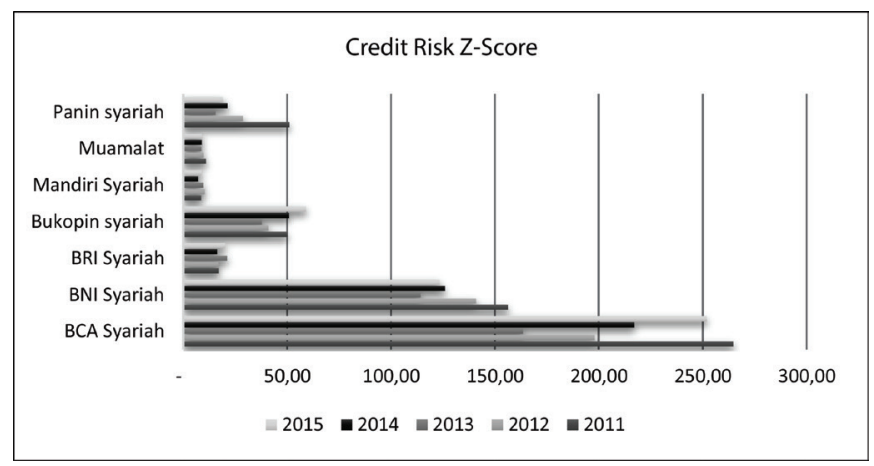

Source: website each Islamic banking and calculate 
In the Figure 2 shows that all the Islamic banks generate credit risk z-score above 0 , it means that Islamic banking in Indonesia has a stable financial system because it is far from the possibility of failure. The first rank that have a good financial stability is Bank of BCA Sharia, with a 260 credit Z-score of 260 in 2011 and 250 by 2015 , this result indicates that the z-score credit risk is far from the number 0 , which means that credit risk is very low. Followed by Bank of BNI Sharia with the value of Credit Z-score of 125 in 2015 and 150 in 2011. Occupying the third position on the high value of $\mathrm{z}$-score is the bank of sharia Bukopin, followed by Bank of Panin Sharia, Bank of BRI sharia, Bank of sharia Mandiri and Bank of Muamalat. This is because the percentage of equity in the bank is higher than other banks. The bank equity other from shares also from the profits generated quite a lot and grow each year.

Figure 3 Composition Equity on Assets

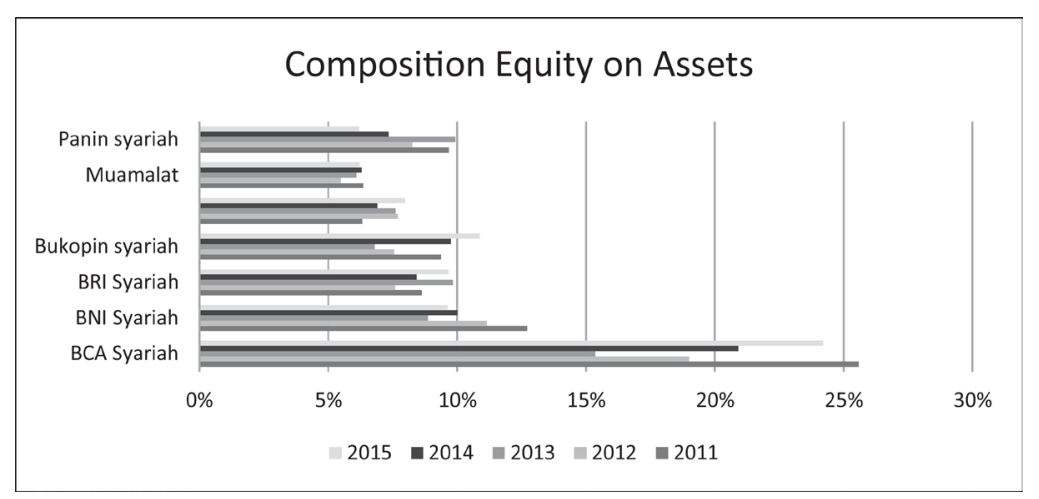

Source: website each Islamic banking and calculate

Besides generating a stable financial data, in this analysis can also be concluded that the amount of equity can increase the endurance to risk on an Islamic banking. Because the source of funds through equity is lower the risk than the debt. This is in compliance with the study of (Shahari et.al., 2015) that reveals the Equity-based financing is lower risk than the Debt based. Equity funding sources has a lower risk because there is no obligation to pay premiums every month and when the company default without a moral hazard factor then the company is not obliged to pay any loss. (Barajas, et.al, 2013; Beck, et.al, 2010; Ernawati, 2016; Faye, et.al, 2013) also said that the bank who has a large equity will be better in managing it's credit risk. The higher the composition of equity this has an impact on the lower credit risk in Islamic banking. 


\section{Analysis Altman Z-Score}

This Altman's Z-score analysis uses accounting data more than the previous analysis. The good results for the financial stability of banking in this analysis tool, if the resulting value is bigger than 2.99 .

Figure 4 Analysis Altman Z-score

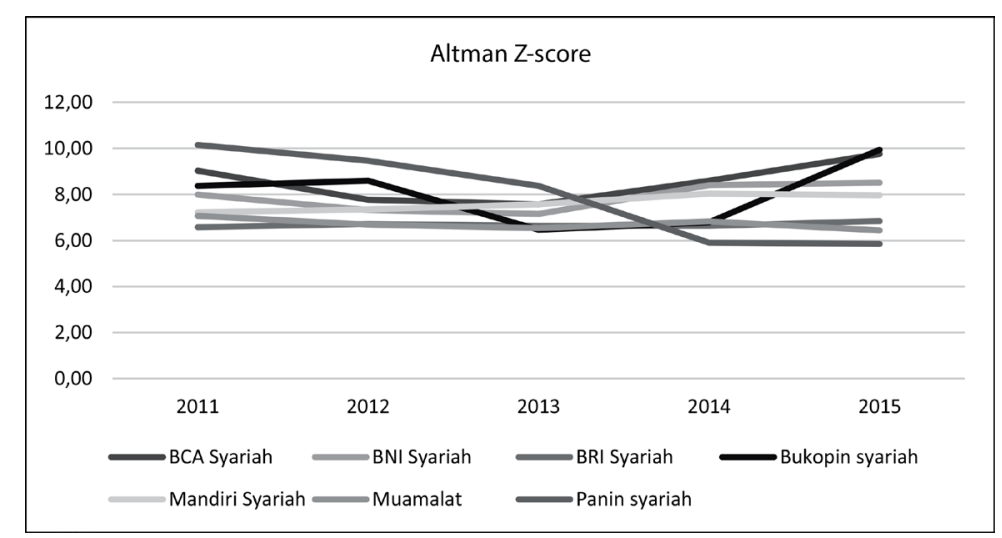

Source: website each Islamic banking and calculate

The result from this analysis is that all Islamic banks in Indonesia maintain their financial stability well because Altman Z-score is generated above 5. This is suggests that the debt-based financing is known to be more risky than equity-based financing by (Shahari et al., 2015) will still be able to maintain the financial stability in the Islamic banking. It's also answered why debt-based financing more attractive than the equity based financing by (Shahari et al., 2015)not only because DBF using collateral and fixed returns guarantees, but also have a lower risk and still be able to maintain the financial stability of Islamic banking well so that far from the possibility of failure. This study is in compliance with the study of (Cihak \& Hesse, 2008; Kabir, et.al, 2015; Rajhi \& Hassairi, 2013).

\section{Conclusion}

This study is telling about the risk of debt-based finacing on Indonesian Islamic banking using an accounting based measurement, those are NPF analysis, Credit Risk Z-score analysis and Altman Z-score analysis. The data was obtained from 2011 to 2015 from the website of each bank. The result is a risk on debt-based financing on Indonesian Islamic is low. The measurement using 3 accounting based measurement tool gives a consistent result, that is Indonesian 
Kharisya Ayu Effendi: Risk of Debt-Based Financing in Indonesian Islamic Banking 211

Islamic banking use a debt-based financing have a high financial stability and a low risk.

\section{References}

Ahmad, N. H. (2007). Multi-Country Study Of Bank Credit Risk Determinants. International Journal of Banking and Finance, 5(1): 135-152.

Alkassim, F. A. (2005). The Profitability of Islamic and Conventional Banking in the GCC Countries: A Comparative Study. Journal of Review of Islamic Economics, 13: 5-30.

Allen, D. E., \& R.J. Powell. (2011). Credit risk measurement methodologies. 19th International Congress on Modelling and Simulation, Perth, Australia., (December), 12-16. Retrieved from http://mssanz.org.au/modsim2011

Altman, E. I., \& A. Saunders. (1998). Credit risk measurement : Developments over the last 20 years. Journal of Banking and Finance, 21: 1721-1742.

Ariss, R. T. (2010). Review of Financial Economics Competitive conditions in Islamic and Conventional Banking : A Global Perspective. Review of Financial Economics, 19(3): 101-108.

Barajas, A., et.al. (2013). Too Cold , Too Hot , Or Just Right? Assessing Financial Sector Development Across the Globe. International Monetary Fund, 1-28.

Beck, T. et.al. (2010). Islamic vs Conventional Banking Business Model, Efficiency and Stability. Policy Research Working Paper, (October).

Beck, T., et.al. (2013). Islamic vs . Conventional Banking: Business Model , Efficiency And Stability. Journal of Banking and Finance, 37(2): 433-447.

Berger, A. N., \& Deyoung, R. (1997). Problem Loans and Cost Efficiency in Commercial Banks. Journal of Banking and Finance, 21 (6): 849-870.

Boyd, J. H., \& Nicoló, G. De. (2003). The Theory of Bank Risk-Taking and Competition Revisited. International Monetary Fund, 1-29.

Cihak, M., \& Hesse, H. (2008). Islamic Banks and Financial Stability : An Empirical Analysis. International Monetary Fund, 1-31.

Das, A., \& Ghosh, S. (2009). Determinants of Credit Risk in Indian State-owned Banks: An Empirical Investigation. Reserve Bank of India. Retrieved from http://mpra.ub.uni-muenchen.de/17301/

Ernawati. (2016). Risk Of Profit Loss Sharing Financing: The Case Of Indonesia. Al-Iqtishad: Jurnal Ilmu Ekonomi Syariah (Journal of Islamic Economics),, 8(1): 101-116. 
Faye, I. et.al. (2013). The Islamic Finance Promises : Evidence From Africa. Review Of Development Finance, 3: 136-151.

Haron, S. (2004). Determinants of Islamic Bank Profitability. Global Journal of Finance and Economics, 1(1), 1-22.

Hasan, M. \& J. Dridi. (2010). The Effects of the Global Crisis on Islamic and Conventional Banks: A Comparative Study. International Monetary Fund, 10: $1-47$.

Johnes, J. et.al (2012). A Comparison of Performance of Islamic and Conventional Banks 2004 to 2009. (Working Paper). Lancaster: Lancaster University

Jiménez, G. et.al. (2007). How Does Competition Impact Bank Risk-Taking? Federal Reserve Bank Of San Francisco Working Paper Series, (September).

Kabir, Md. N., et.al. (2015). Comparative Credit Risk in Islamic and Conventional Banking. Pacific-Basis Finance Journal, 34: 327-353.

Kahf, M. (2005). Islamic Banking And Development: An Alternative Banking Concept ?, (March), 1-15.

Kamaruddin, B. H., et.al. (2008). Assessing Production Efficiency of Islamic Banks and Conventional Bank Islamic Windows in Malaysia. International Journal of Business and Management Research, 1(1), 31-48.

Rajhi, W., \& Hassairi, S. A. (2013). Islamic Banks And Financial Stability: A Comparative Empirical Analysis Between Mena and Southeast Asian Countries. Region et Developpement, 149-177.

Saunders, A. (2008). Financial Institutions Management, A Risk Management (6th ed). New York: McGraw-Hill.

Shahari, F., et.al. (2015). Investigation Of The Expected Loss Of Sharia Credit Instruments In Global Islamic Banks. International Journal Of Managerial, 11(4): 503-512.

Sukmana, R., \& S. Suryaningtyas. (2016). Determinants Of Liquidity Risk In Indonesian. Al-Iqtishad: Jurnal Ilmu Ekonomi Syariah (Journal of Islamic Economics), 8(2): 187-200.

Zaini, M., et.al. (2010). Bank Efficiency And Non-Performing Loans : Evidence From Malaysia And Singapore. Prague Economic Papers, 2: 118-132. 